\title{
RESPIRATORY FUNCTION DURING THE DAY IN COTTON WORKERS: A STUDY IN BYSSINOSIS
}

\author{
BY \\ C. B. McKERROW, M. MCDERMOTT, J. C. GILSON, and R. S. F. SCHILLING \\ From the Pneumoconiosis Research Unit of the Medical Research Council, Llandough Hospital, Nr. Penarth, \\ Glamorgan, and the London School of Hygiene and Tropical Medicine
}

(RECEIVED FOR PUBLICATION NOVEMBER 22, 1957)

Some of the workers in the dustier parts of a cotton mill (card- and blow-rooms) develop byssinosis. They experience tightness of the chest and breathlessness on Mondays or on the first day at work after an absence; these symptoms come on gradually, reaching a peak during the afternoon or early evening. In the early stages (Grade I) the workers feel quite fit by the next day; in the more severely affected the symptoms persist on Tuesdays, and even throughout the week (Grade II). Finally, disability may become permanent and severe (Schilling, Hughes, Dingwall-Fordyce and Gilson, 1955). In this study it was also shown that the ventilatory capacity of the lungs was related to the degree of byssinosis and was lower than in normal controls; in those with byssinosis it was also lower on Monday than Thursday.

The present work was done to study in more detail the short-term effect of mill dust on respiratory function, and to find which simple respiratory test was the most sensitive measure of this effect. We thought that measurement of the change in ventilatory capacity over one day might prove preferable to a comparison between Monday and Thursday by being less affected by variations in weather and other extraneous influences.

In Part I detailed studies on 12 mill workers with clinical byssinosis revealed a consistent pattern of change of ventilatory function within a single day, and in Parts II and III evidence has been obtained that these effects are specific to mill dust.

\section{METHODS}

Ventilatory Capacity

Ventilatory capacity was estimated from the volume expired in 0.75 second during a forced expiration, using an apparatus similar to that described by Gaensler (1951) but modified so that the timing cycle starts after the expulsion of the first $100 \mathrm{ml}$. of air. This reduced the error arising from differences in abruptness of starting expiration. The volume measurement was accurate to $\pm 1.5 \%$ and the timing to $\pm 2.0 \%$. The mean of three results following usually two practice attempts was taken, and multiplied by 40 to give the indirect maximum breathing capacity (indirect M.B.C.) shown by Kennedy (1953) to be highly correlated with and numerically similar to the maximum voluntary ventilation (M.V.V.). The physiological nomenclature is that agreed by a group of physiologists (Gandevia and Hugh-Jones, 1957).

The pneumotachogram was recorded using a large Lilly type flowmeter (Lilly, 1950) in which the differential pressure across a 4 in. diameter screen was measured by a capacitance manometer and recorded on a pen recorder. The system gave a linear response with flow rates up to $1,000 \mathrm{l} . / \mathrm{min}$.

The following measurements were made from the pneumotachograph records:-

(1) The peak expiratory flow during single forced expirations;

(2) the peak inspiratory and expiratory flows during voluntary hyperventilation;

(3) the maximum voluntary ventilation (M.V.V.) by integration of six breaths during hyperventilation.

The mean of two sets of three maximal expirations from full inspiration was taken to obtain the peak expiratory flow, and these were followed after a short rest by two sets of five maximal inspirations and expirations done " as deeply and as quickly as possible ". All subjects chose breathing rates over 60 breaths per minute. The last three breaths from each set were averaged to provide the peak inspiratory and expiratory flows during hyperventilation (peaks maintained over $10 \mathrm{~m} . \mathrm{sec}$.) and also the maximum voluntary ventilation.

\section{Flow Resistance}

The flow resistance of the lungs has two main components: (1) the resistance of the bronchial tree to the movement of air; (2) the frictional resistance involved in the movement of lung tissue.

Measurement of resistance requires simultaneous recordings of air flow and pressure, and the latter presents the greatest difficulty. The only method suitable for use in the present investigation was the " interrupter technique", described originally by Neergaard and Wirz (1927) and elaborated by Vuilleumier (1944). This 


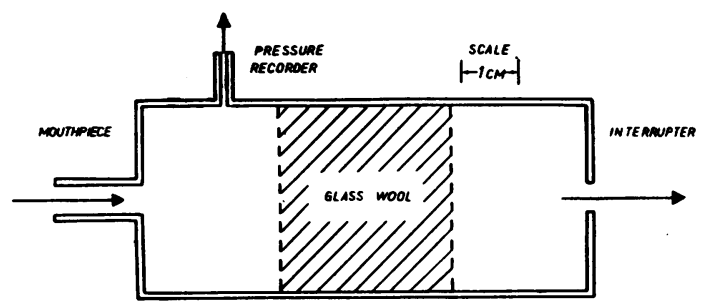

FIG. 1.-Airways resistance apparatus: diagram of the external resistance, the glass wool and interrupter orifice form $\boldsymbol{R}_{\mathbf{E}}$.

method is based on the knowledge that the volume of air in the alveoli is very large compared with that in the airways, hence, if during respiration the airflow at the mouth is instantaneously interrupted (for example, by a rapidly closing shutter in the breathing tube) pressure equilibration will take place throughout the lungs and the mouth pressure will rapidly rise to a value very close to the alveolar pressure before interruption. The resistance of the lung airways can be calculated from the air flow immediately before interruption and the " interrupter pressure".

This technique was further simplified by Ainsworth and Eveleigh (1952), who designed a very ingenious instrument, using an external resistance to eliminate the separate measurement of air flow, and this principle is used in our instrument.

The subject breathes out at a constant flow rate $Q$ (1./sec.) through the external resistance $R_{E}$ (Fig. 1) and the pressure difference $P_{1}\left(\mathrm{~cm} . \mathrm{H}_{2} \mathrm{O}\right)$ is continuously recorded with a pen recorder.

$$
\text { Hence, } \quad P_{1}=R_{E} Q^{n}
$$

(where $n=1.66$ and expresses the degree of turbulence in the external resistance and lung airways, and the pressure drop across $R_{E}$ is $7 \cdot 3 \mathrm{~cm} . \mathrm{H}_{2} \mathrm{O}$ at 1 l./sec.).

The air flow is then interrupted and the recorded pressure rises rapidly to the approximate alveolar pressure, $\boldsymbol{P}_{2}$. The first pressure, $\boldsymbol{P}_{1}$, is that necessary to maintain flow through the external resistance alone, and the second pressure, $P_{2}$, that necessary to maintain the same flow through the lung airways $\left(R_{L}\right)$ and the external resistance, hence $P_{2}-P_{1}$ is the pressure necessary to maintain the flow through the airways.

Therefore,

$$
\begin{gathered}
P_{2}-P_{1}=R_{L} Q^{n} \\
\left(\frac{P_{2}}{P_{1}}-1\right) \dot{R}_{E}=R_{L}
\end{gathered}
$$

from (1)

$\boldsymbol{R}_{E}$ is a constant and its value is known, therefore from the measurements of $\boldsymbol{P}_{1}$ and $\boldsymbol{P}_{\mathbf{2}}$ the lung airways resistance, $R_{L}$, can be calculated. If comparative measurements only are required, expression (3) need not be evaluated,

$$
\left(\frac{P_{2}}{P_{1}}-1\right) \text { being used instead. }
$$

This has been done throughout this paper and is called the airways resistance (A.W.R.) and the results expressed as " units".

The absolute values may be obtained by multiplying the ratio $\left(\frac{P_{2}}{P_{1}}-1\right)$ by the value of the external resistance at 11 . $/ \mathrm{sec} .\left(7 \cdot 3 \mathrm{~cm} . \mathrm{H}_{2} \mathrm{O}\right)$ when the lung airways resistance will be expressed in $\mathrm{cm}$. $\mathrm{H}_{2} \mathrm{O}\left(\mathrm{l} . / \mathrm{sec}\right.$.) ${ }^{1.66}$.

Later work by Mead and Whittenberger (1954) suggests that the " interrupter technique " gives values of resistance which are closer to the total tissue and airways resistance than to those of the airways alone. The average value of $2.6 \mathrm{~cm} . \mathrm{H}_{2} \mathrm{O}$ at $1 \mathrm{l}$./sec. obtained on a group of laboratory subjects using an external resistance is almost identical with the figure obtained by Mead and Whittenberger using separate flow and pressure measurements. In a group of normal subjects the A.W.R. fell about $5 \%$ during the day $(0.10>\mathrm{P}>0.05)$. The mouthpiece resistance $\left(0 \cdot 1 \mathrm{~cm} . \mathrm{H}_{2} \mathrm{O}\right.$ at 11 ./sec.) causes a small (about $10 \%$ ) rise in the value for the lung airways resistance when compared with a large diameter mouthpiece (1 in. diameter).

In Part I, five measurements were made on expiration only over the flow rate 0.5 to 1.51 ./sec.; this was later increased to 12 measurements over the range 0.5 to

\begin{tabular}{|c|c|c|c|c|c|c|}
\hline \multirow{2}{*}{ Subject } & \multirow{2}{*}{ Sex } & \multirow{2}{*}{ Age } & \multirow{2}{*}{ Occupation } & \multirow{2}{*}{$\begin{array}{l}\text { Grade of } \\
\text { Byssinosis }\end{array}$} & \multicolumn{2}{|c|}{ Dyspnoea* } \\
\hline & & & & & On Best Days & On Mondays \\
\hline $\begin{array}{l}1 \\
2 \\
3 \\
4 \\
5 \\
6\end{array}$ & $\begin{array}{l}\mathbf{M} \\
\mathbf{M} \\
\mathbf{F} \\
\mathbf{F} \\
\mathbf{F} \\
\mathbf{F}\end{array}$ & $\begin{array}{l}47 \\
24 \\
58 \\
64 \\
44 \\
66\end{array}$ & $\begin{array}{l}\text { Stripper and grinder } \\
\text { Stripper and grinder } \\
\text { Draw frame tenter } \\
\text { Rover tenter } \\
\text { Slubber tenter } \\
\text { Draw frame tenter }\end{array}$ & I & $\begin{array}{l}\mathbf{I} \\
\mathbf{I} \\
\mathbf{I} \\
\mathbf{I} \\
\mathbf{I} \\
\mathbf{I}\end{array}$ & $\begin{array}{r}\text { I } \\
\mathbf{I} \\
\mathbf{I I} \\
\mathbf{I I} \\
\mathbf{I} \\
\mathbf{I}\end{array}$ \\
\hline $\begin{array}{r}7 \\
8 \\
9 \\
10 \\
11 \\
12\end{array}$ & $\begin{array}{l}\mathbf{M} \\
\mathbf{M} \\
\mathbf{M} \\
\mathbf{M} \\
\mathbf{M} \\
\mathbf{F}\end{array}$ & $\begin{array}{l}44 \\
45 \\
61 \\
63 \\
57 \\
34\end{array}$ & $\begin{array}{l}\text { Blowing-room } \\
\text { Stripper and grinder } \\
\text { Stripper and grinder } \\
\text { Cleaner } \\
\text { Stripper and grinder } \\
\text { Slubber tenter }\end{array}$ & II & $\begin{array}{r}\text { I } \\
\mathbf{I} \\
\mathbf{I I} \\
\mathbf{I I} \\
\mathbf{I}\end{array}$ & $\underset{\text { III }}{\text { II }}$ \\
\hline
\end{tabular}
2.51 . $/ \mathrm{sec}$. (The standard error of a single set of 12

TABLE 1

CARD-ROOM WORKERS WITH BYSSINOSIS IN MILL $A$

*Disability assessment of Schilling et al. (1955).

Grade I = normal

"II = able to keep up with normal men on level only

" III = unable to walk without stopping except at his own speed

" IV = only able to walk 100 yd. without stopping 
readings in untrained individuals is about $11 \%$.) Over this range the degree of turbulence in airways is approximately the same as that in the external resistance. However, one cannot extrapolate directly to obtain values of resistance at flow rates outside these limits.

The main importance of the resistance measurements lies in the fact that no maximal effort is required on the part of the subject, and the results are to a large extent independent of cooperation. This contrasts with all the other tests in this investigation.

All the physiological tests were made with the subjects seated. The indirect M.B.C. results were corrected to body temperature and pressure saturated with water vapour.

\section{PART I}

\section{Subjects with Byssinosis}

\section{Exposed to Mill Dust}

Procedure.-Twelve card-room workers from an Oldham mill (mill $A$ ) were selected as well-defined examples of Grades I and II byssinosis of both sexes (Table 1). The main studies on them were made from Monday to Thursday in one week although they had practised the tests on the previous Friday.

On Monday and Thursday all tests were done at 7.30 a.m. before the subject had entered the cardroom, and again at 9.30 a.m., at 11.30 a.m., at 2.30 p.m., and at 4.30 p.m. On the Tuesday and Wednesday they were done only at $9.30 \mathrm{a} . \mathrm{m}$. and at 4.30 p.m.
FIG. 2.-Daily change in indirect maximum breathing capacity in six subjects of each byssinosis grade in mill $A$. (The midday break, 12 to 1 p.m., was excluded from the period of exposure.)

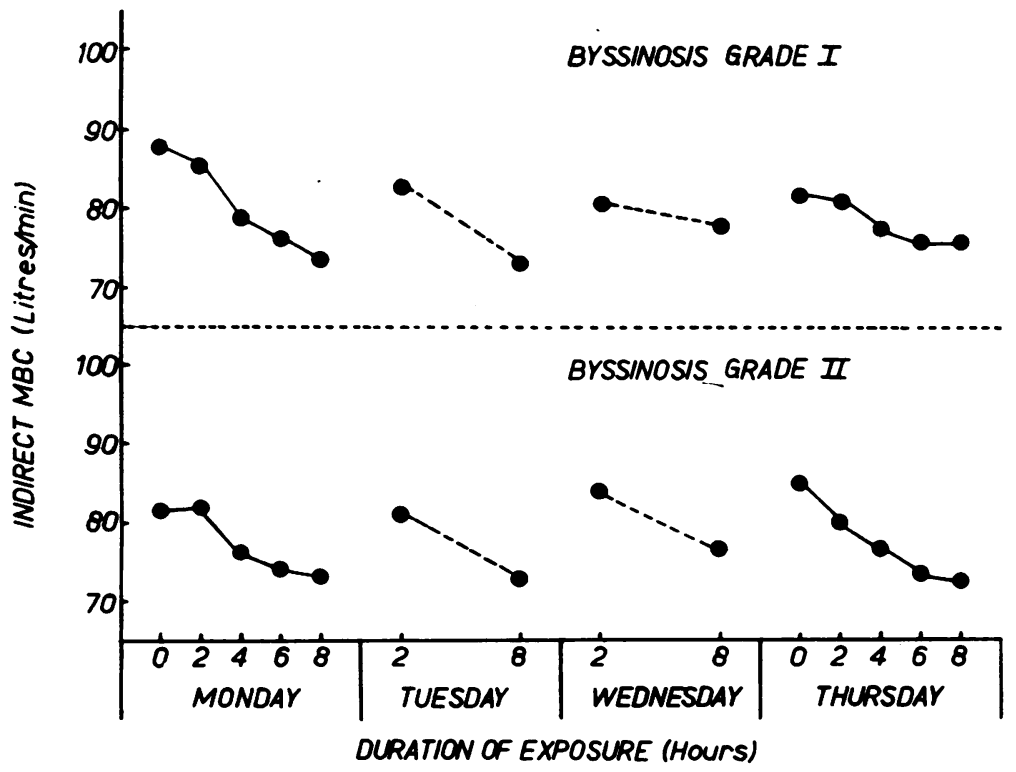

The indirect M.B.C. was measured first and this was followed after a rest of about two minutes by the pneumotachograph records. After a further short rest, the A.W.R. tests were done.

Results.-The results are as follows :

(1) Indirect Maximum Breathing Capacity.-The average changes in indirect M.B.C. during the day for the first four days of the week in those with Grade I and Grade II byssinosis are shown in Fig. 2, and for each subject on Monday and Thursday in Table 2. There is a nearly linear fall of M.B.C.

TABLE 2

CHANGE OF INDIRECT MAXIMUM BREATHING CAPACITY AND PEAK EXPIRATORY FLOW (SINGLE BREATHS) DURING HOURS OF WORK

\begin{tabular}{|c|c|c|c|c|c|}
\hline \multirow{2}{*}{ Subject } & \multirow{2}{*}{$\begin{array}{l}\text { Grade of } \\
\text { Byssinosis }\end{array}$} & \multicolumn{2}{|c|}{$\begin{array}{l}\text { Change of Indirect M.B.C. } \\
(1 . / \mathrm{min} . / \text { hour }) \dagger\end{array}$} & \multicolumn{2}{|c|}{ Change of Peak Expiratory Flow } \\
\hline & & Monday & Thursday & Monday & Thursday \\
\hline $\begin{array}{l}1 \\
2 \\
3 \\
4 \\
5 \\
6\end{array}$ & I & $\begin{array}{l}-2.10^{*} \\
-1.78^{*} \\
-1.63^{*} \\
-3.10^{*} \\
-0.37 \\
-0.84^{*}\end{array}$ & $\begin{array}{l}-0.65^{*} \\
-0.02 \\
-0.72^{*} \\
-1.55^{*} \\
+0.13 \\
-1.49^{*}\end{array}$ & $\begin{array}{r}-8.33 \\
+1.93 \\
+1.35 \\
-6.38 \\
-1.26 \\
+1.00\end{array}$ & $\begin{array}{r}-4.79 \\
+4.05 \\
-3.95 \\
-6.97 \\
-1.59 \\
-6.13\end{array}$ \\
\hline $\begin{array}{r}7 \\
8 \\
9 \\
10 \\
11 \\
12\end{array}$ & II & $\begin{array}{l}+0.62^{*} \\
-1.03^{*} \\
-3.34^{*} \\
-0.80^{*} \\
-1.39^{*} \\
-0.71^{*}\end{array}$ & $\begin{array}{l}-0.69^{*} \\
-0.71^{*} \\
-3.00^{*} \\
-2.09^{*} \\
+0.39^{*} \\
-0.61^{*}\end{array}$ & $\begin{array}{c}-4.14 \\
+1.79 \\
-6.19^{*} \\
-6.13 \\
-6.50\end{array}$ & $\begin{array}{r}-7.43 \\
-2.62 \\
-11.52^{*} \\
-8.37^{*} \\
-1.45\end{array}$ \\
\hline Mean & $\mathbf{I}$ & $-1.64^{*}$ & $-0.71^{*}$ & -1.95 & $-3 \cdot 23^{*}$ \\
\hline Mean & II & $-1 \cdot 11^{*}$ & $-1 \cdot 12^{*}$ & $-4 \cdot 24^{*}$ & $-6 \cdot 28^{*}$ \\
\hline
\end{tabular}

\footnotetext{
*Change significant at $5 \%$ level. †Regression coefficients.
} 
FIG. 3.-Daily change in peak expiratory flow rate in single breaths $(x)$, in peak expiratory flow rate during hyperventilation $(\bullet)$, and in peak inspiratory flow rate during hyperventilation $(O)$.

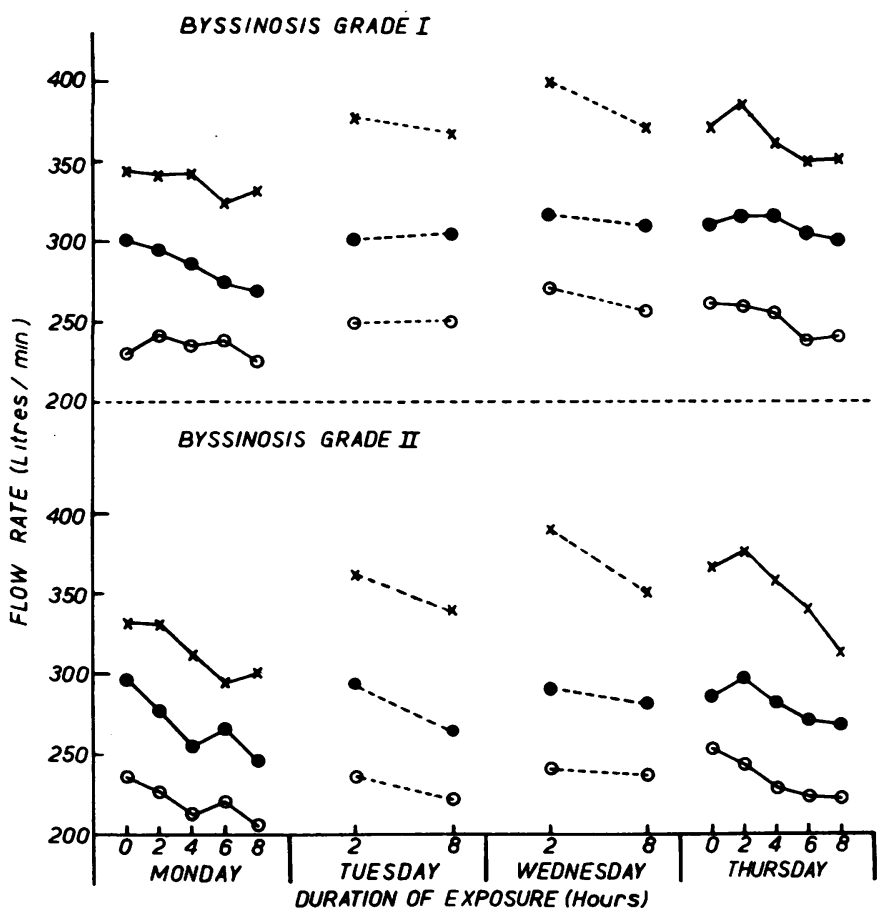

of inspiratory resistance. The flow during hyperventilation rather than single breaths was chosen as untrained subjects find a single forced inspiration difficult to do. Fig. 3 shows that there was greater variability in the pattern of change during the day and from day to day of the peak inspiratory flow than in the case of the indirect M.B.C. The peak expiratory flow during hyperventilation showed a trend generally similar to that measured on single breaths but the rise of the initial daily reading during the week was smaller. A comparison between the various tests is given in Table 3 where the change during the day is expressed as percentage per hour derived from the regression coefficients of the results grouped by byssinosis grade.

(4) Maximum Voluntary Ventilation. -The measurement of M.V.V. derived from the integration of six breaths recorded on the pneumotachograph showed a pattern of change very similar to the indirect M.B.C. and with a slightly greater fall during the day, but less differentiation between byssinosis Grades I and II (Table 3).

(5) Airways Resistance.-The averduring the whole of the working day and this is significant $(P<0.05)$ in all except one subject on Monday, and two on Thursday. Fig. 2 indicates that the subjects recovered partially overnight. The mean fall of $1.641 . / \mathrm{min}$./hour in Grade I on Monday is significantly greater than $0.71 \mathrm{1} . / \mathrm{min}$./hour on Thursday, whereas in Grade II the fall is almost identical on the two days.

(2) Peak Expiratory Flow (Single Breaths).-The peak expiratory flow during forced expiration is shown in Fig. 3 and Table 2 . Each figure is the mean of the six observations. There is a tendency for the peak flow to fall during the day, but the trend is less constant than that seen in the indirect M.B.C. In fact, three subjects in Grade I and one in Grade II on the Monday showed a rise which was not statistically significant. There were only three statistically significant falls in the whole group on Monday and Thursday combined. In addition the average value of peak flow in most subjects tended to rise during the week-possibly a learning effect.

(3) Inspiratory and Expiratory Peak Flow during Hyperventilation.-The peak inspiratory flow is of interest as possibly giving an estimate of the change age changes in resistance are shown in Fig. 4 and Table 3. In both groups there is an increase during the day, the changes being greater in Grade II than in Grade I. On Monday four out of six subjects in Grade I showed an increase in airways resistance, although the average change for the group is not significant. In Grade II four out of five subjects showed an increase during the day and the average change for the group is significant $(P<0.05)$. On Thursday the changes were again significant in Grade II but not in Grade I. The range of percentage changes is greater for resistance than for the M.B.C. and flow measurements, two subjects in Grade II showing an increase of more than $100 \%$.

\section{PART II}

\section{Control Studies}

Subjects with Byssinosis Working away from Cotton Dust.-Of the 12 workers already studied, eight were chosen whose indirect M.B.C. had fallen considerably during the day. These people were examined again in two groups of four on two successive Mondays. On the first day one group did light work in the mill, but away from the card- 
rooms, while the members of the other worked at their usual jobs in the card-room. On the second Monday the groups were reversed.

All the individuals again showed a reduction in the indirect M.B.C. when in the card-room and in all except one this fall was either reversed or reduced when away from it. The mean percentage fall in indirect M.B.C. of $19.7 \%$ when in dust (Table 4) is significantly different from that of $2.8 \%$ when working out of it $(0.02>P>0.01)$.

The A.W.R. increased in only four of the individuals during the day's work in the card-room, but in all except one it fell during the day outside it. The mean difference in change on the two occasions was not statistically significant $(P>0.1)$.

Effect of Adrenaline.-As a further demonstration that some active process was taking place in these subjects with byssinosis when working in the cardroom, we tested the effect on the ventilatory capacity of the inhalation of neb.adrenaline et atropine co. (National Formulary) after the day's work. Six subjects were given the inhalations from a nebulizer for five minutes on a Monday at 4.30 p.m. and its effect was compared with that of a similar inhalation given on a Friday morning within two

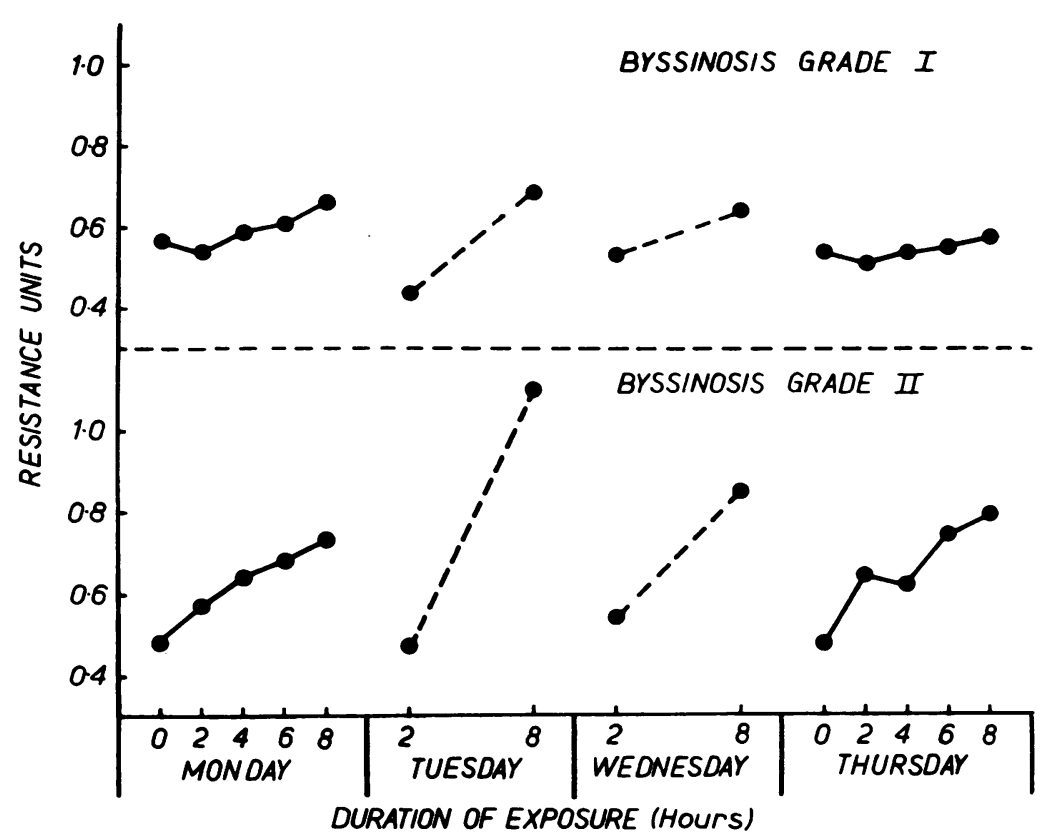

hours of starting work. In normal subjects little change in ventilatory capacity would be expected after adrenaline (Gilson and Hugh-Jones, 1955). On Monday the mean indirect M.B.C. of the group fell from $68 \cdot 21 . / \mathrm{min}$. to $53 \cdot 21 . / \mathrm{min}$. during the day's work but returned again to $65.61 . / \mathrm{min}$. after the adrenaline inhalation, and this was accompanied by subjective improvement in some subjects. On Friday the initial reading at 9.30 a.m. was $62.21 . / \mathrm{min}$. and the inhalation raised this to $67 \cdot 81 . / \mathrm{min}$. The

TABLE 3

PERCENTAGE CHANGES IN VENTILATORY TESTS PER HOUR OF WORK

\begin{tabular}{|c|c|c|c|c|c|}
\hline \multirow[b]{2}{*}{ Test } & \multirow{2}{*}{$\begin{array}{l}\text { Grade of } \\
\text { Byssinosis }\end{array}$} & \multicolumn{2}{|c|}{ Monday } & \multicolumn{2}{|c|}{ Thursday } \\
\hline & & $\begin{array}{c}\text { First Reading } \\
\text { (7.30 a.m.) } \\
\text { (1./min.) }\end{array}$ & $\%$ Change/Hour & $\begin{array}{c}\text { First Reading } \\
\text { (7.30 a.m.) } \\
\text { (1. / min.) }\end{array}$ & $\%$ Change/Hour \\
\hline $\begin{array}{l}\text { Indirect M.B.C. } \\
\text { Peak expiratory flow } \\
\text { Peak inspiratory flow (hyperventilation) } \\
\text { Peak expiratory flow (hyperventilation) } \\
\text { M.V.V. }\end{array}$ & $\begin{array}{l}\text { I } \\
\text { II } \\
\text { I } \\
\text { II } \\
\text { II } \\
\text { II } \\
\text { II } \\
\text { II } \\
\text { II }\end{array}$ & $\begin{array}{c}87.6 \\
81 \cdot 9 \\
344 \\
331 \\
230 \\
236 \\
301 \\
296 \\
90 \cdot 8 \\
91 \cdot 8\end{array}$ & $\begin{array}{l}-1.87 \\
=1.36 \\
-0.57 \\
-1.28 \\
=0.28 \\
=1.17 \\
=1.23 \\
-1.62 \\
-2.06 \\
-2.05\end{array}$ & $\begin{array}{c}81 \cdot 7 \\
82 \cdot 4 \\
372 \\
366 \\
262 \\
253 \\
321 \\
286 \\
96 \cdot 8 \\
86 \cdot 8\end{array}$ & $\begin{array}{l}-0.87 \\
=1.36 \\
-0.87 \\
-1.72 \\
-1.07 \\
-1.38 \\
-0.63 \\
-0.98 \\
-1.90 \\
-1.65\end{array}$ \\
\hline & & $\begin{array}{c}\text { First Reading } \\
\text { (resistance units) }\end{array}$ & $\%$ Change/Hour & $\begin{array}{c}\text { First Reading } \\
\text { (resistance units) }\end{array}$ & $\%$ Change/Hour \\
\hline A.W.R. & II & $\begin{array}{l}0.57 \\
0.48\end{array}$ & $\begin{array}{l}+1.7 \\
+7.6\end{array}$ & $\begin{array}{l}0.54 \\
0.48\end{array}$ & $\begin{array}{l}+1.1 \\
+6.1\end{array}$ \\
\hline
\end{tabular}


TABLE 4

CHANGES IN INDIRECT MAXIMUM BREATHING CAPACITY AND AIRWAYS RESISTANCE OF EIGHT SUBJECTS IN AND OUT OF CARD-ROOM ON A MONDAY

\begin{tabular}{|c|c|c|c|c|c|c|c|c|}
\hline \multirow{3}{*}{ Time } & \multicolumn{4}{|c|}{ Indirect M.B.C. } & \multicolumn{4}{|c|}{ A.W.R. } \\
\hline & \multicolumn{2}{|c|}{ In Card-room } & \multicolumn{2}{|c|}{ Out of Card-room } & \multicolumn{2}{|c|}{ In Card-room } & \multicolumn{2}{|c|}{ Out of Card-room } \\
\hline & $1 . / \mathrm{min}$. & $\%$ Change & $1 . / \mathrm{min}$. & $\%$ Change & Units & $\%$ Change & Units & $\%$ Change \\
\hline $\begin{array}{r}8 \text { a.m. } \\
11 \text { a.m. } \\
4 \text { p.m. }\end{array}$ & $\begin{array}{l}79 \cdot 3 \\
71 \cdot 9 \\
63 \cdot 7\end{array}$ & $\begin{array}{r}\overline{9} \cdot 3 \\
-19 \cdot 7^{*}\end{array}$ & $\begin{array}{l}81.6 \\
83.7 \\
79.3\end{array}$ & $\begin{array}{l}\overline{+2} \cdot 6 \\
-2 \cdot 8^{*}\end{array}$ & $\begin{array}{l}0.63 \\
0.80 \\
0.84\end{array}$ & $\begin{array}{r}\overline{22} \cdot 8 \\
+25 \cdot 6\end{array}$ & $\begin{array}{l}0.68 \\
0.62 \\
0.59\end{array}$ & $\begin{array}{r}\overline{-1.9} \\
-7.8\end{array}$ \\
\hline
\end{tabular}

*These figures differ significantly from one another $(0.02>P>0.01)$.

rather low initial reading suggested that some bronchospasm was already present, confirming the trends during the week seen in Part $I$.

Cotton-workers without Byssinosis.-Twelve cardroom workers from the same mill as those already described, and of similar ages and working conditions but without any symptoms of byssinosis, were seen three times on a Monday. Six showed a fall of ventilatory capacity, one a rise, and five little change during the day. Table 5 gives the mean results together with those for the subjects with byssinosis over a similar period of time for comparison. A small fall of $4 \cdot 81 . / \mathrm{min}$. $(6.0 \%)$ occurred which is not statistically significant $(0 \cdot 1>P>0.05)$. The fall is less than half that seen in those with byssinosis.

The airways resistance was measured in 10 cottonworkers without byssinosis (Table 6); the mean increase of 0.08 units $(9.8 \%)$ is statistically insignificant $(P>0.5)$. Further results of comparisons of those with and without byssinosis are given in Part III.

Coal-miners Exposed to Dust on the Coal-face.Studies so far made strongly suggested that something in the mill dust or the job was causing changes in lung function but it was necessary to exclude the possibility that they were the result of the physiological or psychological effects of fatigue, or due simply to the irritation of a dust which was not pharmacologically active. The change in airways resistance suggests a cause other than fatigue, as little effort is needed for the test.

As a further check we studied a group of coalface workers in a South Wales mine on a Monday morning at 7 a.m. before their shift, and again at 2 p.m. after it. Dust sampling in the mine showed that they were exposed to an average total dust concentration of $21.2 \mathrm{mg} . / \mathrm{m}^{3}$ which was about four times the concentration in mill $B$ (see Part III). The comparison is given for total dust because we are probably concerned with coarse $(>5 \mu)$ as well as fine dust. If the changes in the byssinotic subjects were related simply to the inhalation of inert dust, one would expect to see similar changes at least as great in the miners.

The group of 33 miners were all those available who were working on two coal-faces. Their average age of 29.6 years was considerably lower than that of the cotton workers. However, examination of the individual results of the miners showed no trend of change with age, and likewise the results

TABLE 5

CHANGES IN INDIRECT MAXIMUM BREATHING CAPACITY IN CARD-ROOM WORKERS IN MILL $A$ ON A MONDAY

\begin{tabular}{|c|c|c|c|c|c|c|}
\hline \multirow{2}{*}{ Time } & \multicolumn{2}{|c|}{$\begin{array}{l}\text { No Byssinosis } \\
\text { (12 subjects) }\end{array}$} & \multicolumn{2}{|c|}{$\begin{array}{c}\text { Grade I Byssinosis } \\
\text { (6 subjects) }\end{array}$} & \multicolumn{2}{|c|}{$\begin{array}{c}\text { Grade II Byssinosis } \\
\text { (6 subjects) }\end{array}$} \\
\hline & $1 . / \mathrm{min}$ & $\%$ Change & $1 . / \mathrm{min}$. & $\%$ Change & $1 . / \mathrm{min}$ & $\%$ Change \\
\hline $\begin{array}{l}9 \text { to } 9.30 \text { a.m. } \\
2 \text { to } 2.30 \text { p.m. } \\
4.30 \text { p.m. }\end{array}$ & $\begin{array}{l}76 \cdot 8 \\
74 \cdot 0 \\
72 \cdot 0\end{array}$ & $\begin{array}{l}-\overline{3 \cdot 6} \\
-6 \cdot 0\end{array}$ & $\begin{array}{l}85 \cdot 3 \\
76 \cdot 0 \\
73 \cdot 4\end{array}$ & $\begin{array}{l}-\overline{15 \cdot 0} \\
-15 \cdot 4\end{array}$ & $\begin{array}{l}82 \cdot 0 \\
74 \cdot 1 \\
73 \cdot 2\end{array}$ & $\begin{array}{l}\overline{10 \cdot 4} \\
-12 \cdot 3\end{array}$ \\
\hline
\end{tabular}

TABLE 6

CHANGES IN AIRWAYS RESISTANCE IN CARD-ROOM WORKERS IN MILL $A$ ON A MONDAY

\begin{tabular}{|c|c|c|c|c|c|c|}
\hline \multirow{2}{*}{ Time } & \multicolumn{2}{|c|}{$\begin{array}{l}\text { No Byssinosis } \\
\text { (10 subjects) }\end{array}$} & \multicolumn{2}{|c|}{$\begin{array}{c}\text { Grade I Byssinosis } \\
\text { (6 subjects) }\end{array}$} & \multicolumn{2}{|c|}{$\begin{array}{c}\text { Grade II Byssinosis } \\
\text { (5 subjects) }\end{array}$} \\
\hline & Units & $\%$ Change & Units & $\%$ Change & Units & $\%$ Change \\
\hline $\begin{array}{l}9 \text { to } 9.30 \text { a.m. } \\
2 \text { to } 2.30 \text { p.m. } \\
4.30 \text { p.m. }\end{array}$ & $\begin{array}{l}0.68 \\
0.73 \\
0.76\end{array}$ & $\begin{array}{l}\overline{+5.5} \\
+9 \cdot 8\end{array}$ & $\begin{array}{l}0.54 \\
0.61 \\
0.66\end{array}$ & $\begin{array}{r}\overline{14.4} \\
+21.6\end{array}$ & $\begin{array}{l}0.57 \\
0.68 \\
0 \cdot 75\end{array}$ & $\begin{array}{l}+\overline{24} \cdot 3 \\
+37 \cdot 3\end{array}$ \\
\hline
\end{tabular}


on cotton workers have shown no close relationship between age and the change of ventilatory capacity during a Monday. The average working time underground was 14.6 years. Twenty-three of the miners had normal radiographs, five had Category 1 and two Category 2 simple pneumoconiosis (including one with Category $\boldsymbol{A}$ complicated pneumoconiosis). Three were not examined radiologically.

Table 7 gives the average change of indirect M.B.C.

TABLE 7

CHANGES IN INDIRECT MAXIMUM BREATHING CAPACITY AND IN AIRWAYS RESISTANCE IN THE MINERS ON A MONDAY

\begin{tabular}{|c|c|c|}
\hline Time & $\begin{array}{c}\text { Indirect } \\
\text { M.B.C. (1./min.) } \\
\text { (33 subjects) }\end{array}$ & $\begin{array}{c}\text { Airways } \\
\text { Resistance (units) } \\
\text { (19 subjects) }\end{array}$ \\
\hline $\begin{array}{l}7 \text { a.m. } \\
2 \text { p.m. }\end{array}$ & $\begin{array}{l}131.8 \\
135.0\end{array}$ & $\begin{array}{l}0.45 \\
0.42\end{array}$ \\
\hline$\%$ Change & $+3.8 \%$ & $-5 \cdot 5 \%$ \\
\hline
\end{tabular}

in all subjects and of the A.W.R. in 19 (the maximum number who could be examined in the time available). The significant rise in M.B.C. of $3.8 \%$ and the fall in A.W.R. of $5.5 \%$ are in sharp contrast to the results for the cotton workers in mill dust. Similar slight increases in M.B.C. after work in coal-mines have been reported by Worth, Valentin, Venrath, Gasthaus, and Hoffmann (1956) and by G̣ielen (1957).

\section{PART III}

\section{A Card-room Population before and after Dust Suppression}

In another mill (mill $B$ ) which had a high prevalence of byssinosis in its card-room workers $(37 \%$ in the two grades of byssinosis), vacuum dust extraction of a new type developed by the Shirley Institute (Ministry of Labour and National Service, 1957) was about to be installed on each carding engine. We therefore decided to see whether improvement in dustiness could be detected physiologically.

Clinical assessments of one card-room population were made and over $90 \%$ of the population agreed to cooperate in the initial studies during a Monday before the installation of the dust suppression equipment. Ten months later and three weeks after the completion of the installation there were 39 of the 51 card-room workers originally examined still at the mill. The same tests were repeated by the same observers.

The total dust concentration at the time of the first survey was $4.6 \mathrm{mg} . / \mathrm{m}^{3}$ and during the second after dust suppression $2.4 \mathrm{mg} . / \mathrm{m}^{3}{ }^{3}$

Table 8 shows the average change in indirect M.B.C. in all 51 subjects, and in A.W.R. in 27 at the time of the first survey related to byssinosis grade. In contrast to the finding in mill $\boldsymbol{A}$ where the subjects were selected on the basis of having undoubted byssinosis Grades I and II, or of being quite free from symptoms, there is in mill $B$ an average fall in M.B.C. and rise of A.W.R. not closely related to clinical assessment of the severity of byssinosis. The changes in the groups as a whole are, however, significant $(P \simeq 0.001$ in the M.B.C. and $0.01>P>0.005$ in the A.W.R.).

In this comparatively large group, it is of interest to relate the absolute change in M.B.C. during the day to age. The relation appears extremely poor. The correlation did not approach significance $(r<0 \cdot 2)$.

Table 9 gives a comparison of the changes on a

TABLE 9

CHANGES IN INDIRECT MAXIMUM BREATHING CAPACITY AND IN AIRWAYS RESISTANCE ON A MONDAY
IN MILL $B$ BEFORE AND AFTER DUST SUPPRESSION

\begin{tabular}{|c|c|c|c|}
\hline & Time & $\begin{array}{c}\text { Indirect } \\
\text { M.B.C. (1./min.) } \\
\text { (39 subjects) }\end{array}$ & $\begin{array}{c}\text { Airways } \\
\text { Resistance (units) } \\
\text { (19 subjects) }\end{array}$ \\
\hline \multirow{2}{*}{$\begin{array}{c}\text { Before } \\
\text { Dust } \\
\text { Suppression }\end{array}$} & $\begin{array}{l}8 \text { a.m. } \\
4.30 \text { p.m. }\end{array}$ & $\begin{array}{l}90.6 \\
83.9 \\
\end{array}$ & $\begin{array}{l}0.47 \\
0.66\end{array}$ \\
\hline & $\%$ Change & $-8.7 \%$ & $+36.1 \%$ \\
\hline \multirow{2}{*}{$\begin{array}{c}\text { After } \\
\text { Dust } \\
\text { Suppression }\end{array}$} & $\begin{array}{l}8 \text { a.m. } \\
4.30 \text { p.m. }\end{array}$ & $\begin{array}{l}90 \cdot 6 \\
88 \cdot 1\end{array}$ & $\begin{array}{l}0.51 \\
0.50\end{array}$ \\
\hline & $\%$ Change & $-3.7 \%$ & $-2 \cdot 4 \%$ \\
\hline
\end{tabular}

The change during the day before dust suppression is significantly different from the change after dust suppression in both tests : ( $P<0.05$ in the M.B.C. and $P<0.01$ in the A.W.R.)

TABLE 8

CHANGES IN INDIRECT MAXIMUM BREATHING CAPACITY AND IN AIRWAYS RESISTANCE ON A MONDAY IN MILL $B$ BEFORE DUST SUPPRESSION

\begin{tabular}{|c|c|c|c|c|c|c|}
\hline \multirow[b]{2}{*}{ Time } & \multicolumn{3}{|c|}{ Indirect M.B.C. (1./min.) } & \multicolumn{3}{|c|}{ Airways Resistance (units) } \\
\hline & $\begin{array}{c}\text { No Byssinosis } \\
\text { (32 subjects) }\end{array}$ & $\begin{array}{c}\text { Grade I } \\
\text { (14 subjects) }\end{array}$ & $\begin{array}{c}\text { Grade II } \\
\text { (5 subjects) }\end{array}$ & $\begin{array}{l}\text { No Byssinosis } \\
\text { (15 subjects) }\end{array}$ & $\begin{array}{c}\text { Grade I } \\
(8 \text { subjects) }\end{array}$ & $\begin{array}{c}\text { Grade II } \\
\text { (4 subjects) }\end{array}$ \\
\hline $\begin{array}{l}8 \text { a.m. } \\
4.30 \text { p.m. }\end{array}$ & $\begin{array}{l}88 \cdot 0 \\
82 \cdot 0\end{array}$ & $\begin{array}{l}94 \cdot 9 \\
87 \cdot 6\end{array}$ & $\begin{array}{l}72 \cdot 7 \\
68 \cdot 1\end{array}$ & $\begin{array}{l}0.50 \\
0.72\end{array}$ & $\begin{array}{l}0.55 \\
0.61\end{array}$ & $\begin{array}{l}0.47 \\
0.61\end{array}$ \\
\hline$\%$ Change & $-7.9 \%$ & $-8 \cdot 2 \%$ & $-9 \cdot 3 \%$ & $+39.1 \%$ & $+20.8 \%$ & $+29.8 \%$ \\
\hline
\end{tabular}

The changes during the day are significant $(P \simeq 0.001)$ in the M.B.C. of the whole group of 51 subjects and in the A.W.R. $(0.01>P>0.005)$ in the group of 27 subjects examined. 
Monday before and after dust suppression in those subjects examined on both occasions. It can be seen that there is now less than half the change in the indirect M.B.C. and the change of airways resistance during the day has altered from a rise of $36 \%$ to a fall of $2 \%$. These differences on the two occasions are significant $(P<0.05$ in the M.B.C. and $P<0.01$ in the A.W.R.).

\section{DISCUSSION \\ Specificity of Lung Function Changes}

The relationship of work or environment in the mill to lung function measured by two tests of ventilatory function has been demonstrated by removing eight subjects from the card-room for a day, when no significant changes were observed. As the exertion was less when out of card-rooms the effect of fatigue could not be excluded, but the findings in a group of miners working on the coalface show that neither the fatigue of heavy exertion nor the inhalation of an inert dust such as coal could be responsible for the changes. We are, therefore, justified in concluding that the mill dust is the cause of the respiratory impairment, and that it contains some pharmacologically active constituent. The reduced effect on lung function in mill $B$ after the dust levels had been lowered shows that a quantitative dose response relationship exists. The form of this relationship is under investigation.

\section{Relation of Respiratory Changes to Degree of} Byssinosis and to the Day of the Week

In the initial group of subjects selected as welldefined examples of byssinosis Grades I and II, and the group without any symptoms of byssinosis, there was a fairly clear-cut relationship between the degree of byssinosis and the change taking place during a Monday. However, in the representative sample of all card-room workers in mill $B$ no clear relationship persists. The difference may be the result of the difference in selection. There seems no doubt that those without clear-cut byssinosis do frequently also show some change of ventilatory function during the day. Thus, physiological tests reveal changes before disability is detectable clinically.

The greater change in ventilatory capacity on Monday than on Thursday in Grade I is in accord with the clinical symptoms characteristic of the group. It seems possible that it is the rate of change which is detected by the subject. In Grade II the rate of fall is much the same on Monday and Thursday and it is a feature of this grade that the symptoms persist throughout the week.

The nearly linear decline of the maximum breath- ing capacity during the Monday suggests that the type of response is very different from that observed in the asthmatic. Further work is in progress to relate the dust exposure of the individual during his working day to the physiological changes on that day. It is probable that some of the variability of the response seen in the subjects reported here is the result of actual variations in dose received, because the time actually spent in the card-room varies from man to man and from job to job in this part of the mill.

\section{The Pharmacological Mechanism of the Changes}

It is not yet possible to state how the active constituent produces its effect-whether by causing oedema or broncho-constriction, or both. The nearly complete reversal of the changes by adrenaline does not permit separation of these two possible effects. Preliminary studies using mepyramine do not suggest that the effect is readily reversed by anti-histaminic drugs.

The incomplete recovery of ventilatory capacity over a single night is to be expected because elimination of dust from the bronchial tree takes more than 12 hours. The cause of the smaller response in the Grade I subjects on Thursday than on Monday is uncertain. It is improbable that it is the result of a lower dust concentration on Thursday because extensive studies in other mills have shown that there is no general trend for the dust concentration to fall during the week, nor do the results in the Grade II subjects suggest it in this instance.

The finding that the airways resistance returned to normal while the indirect M.B.C. was still affected when the dust level was reduced from $4.6 \mathrm{mg} . / \mathrm{m}^{3}$ to $2.4 \mathrm{mg} . / \mathrm{m}^{3}$ needs comment. The A.W.R. is a less sensitive test than the indirect M.B.C. when the deviation from normal is small. But when gross changes are present the rise in the A.W.R. is more impressive than the fall in M.B.C. This is well seen in Figs. 2 and 4 where the rise of A.W.R. during the day in the Grade II cases is very marked.

It is also possible that the change in size distribution of the dust brought about by the dust suppression equipment and which preferentially removes the larger respirable sizes may be important. The A.W.R. may be more affected by changes occurring in the larger airways in which the larger particles are deposited. Much more work is needed to elucidate the pharmacological mechanism fully.

The present work cannot exclude Prausnitz' view (Prausnitz, 1936) that the pathological changes specific to the disease are thickening of the alveolar walls from irritating soluble proteins in the cotton dust, but the reversible physiological effects which 
we have found cannot be ascribed to this pathology. Some of the subjects showing the largest change of airways resistance have also been hoarse towards the end of the working day, which further indicates that the active substance may be affecting the upper respiratory tract.

\section{Choice of Tests}

The indirect M.B.C. was the most stable test and showed the most consistent change with the duration of dust exposure (Fig. 2), although the maximum voluntary ventilation derived from the integrated pneumotachogram showed a slightly greater fall during the day in those with byssinosis (Table 3). However, we did not choose this test for the studies in Parts II and III because it requires more effort from the subject and its analysis is much more laborious. The peak expiratory flow rate on a single breath was unsatisfactory because of its variability from reading to reading, and its tendency to increase during the week to values higher than the initial one on Monday. Although the interrupter method of measuring the airways resistance may include a part of the tissue viscous resistance as well as the air flow resistance it was used as the only method at present possible for application in the field. The test also has the great advantage that as it requires no maximal effort on the part of the subject, it is most unlikely to be affected by fatigue or cooperation and so provides valuable additional evidence of the validity of the changes of function in the lung. The indirect M.B.C. and A.W.R. results are not very highly correlated, but in the present state of knowledge of the mechanics of respiration it is not possible to assess the full physiological significance of either test. The change of airways resistance expressed either in absolute units or as a percentage of the initial reading is greater than for the indirect M.B.C. but there are also more individuals who give inconsistent readings.

\section{SUMMARY}

Twelve subjects selected clinically as having welldefined Grades I and II byssinosis were studied at their work in the card-rooms during each day throughout a week. The indirect maximum breathing capacity (indirect M.B.C.) fell nearly linearly during the day. On Monday the fall in Grade I was $1.61 . / \mathrm{min} . / \mathrm{hr}$. and in Grade II $1.11 \mathrm{l} / \mathrm{min}$./hr. On Thursday the fall was similar in Grade II but less marked in Grade I. The airways resistance (A.W.R.) measured by an interrupter technique increased on Monday by $1.7 \% / \mathrm{hr}$. in Grade I, and $7.6 \% / \mathrm{hr}$. in Grade II. Twelve card-room workers without byssinosis showed changes of M.B.C. and A.W.R. less than half as great as those with byssinosis.

Similar changes were observed in a complete card-room population but the relationship of the change to the grade of byssinosis was less clear cut.

The peak expiratory flow on forced expiration, and the inspiratory and expiratory peak flows on hyperventilation showed similar but less consistent changes.

Removal of subjects from the card-room prevented the changes. Also, 39 workers in another card-room studied before and after the installation of dust suppression equipment showed that reducing the dustiness reduced the fall of ventilatory capacity.

A group of coal-miners was examined before and after a shift on a coal-face where the dust concentrations were about four times as high as those in the card-room. There was an average small rise in M.B.C. and a fall in A.W.R. which contrasted sharply with the findings in cotton-workers.

We conclude that there is a pharmacologically active constituent in the mill dust causing the changes in ventilatory carazity. The mechanism of its action is discussed.

We should like to thank the staff and workers of the cotton mills and of the coal-mine whose cooperation made this study possible.

We are grateful also to many of our colleagues, especially to Mr. P. D. Oldham and Miss Barbara Snow for statistical help, to Dr. I. T. T. Higgins who did part of the clinical examinations, to Mr. S. A. Roach for the dust estimations, to Dr. R. Routledge, of the Medical Service of the National Coal Board, for assistance in the examination of the miners, and to Miss Margaret Collins for technical help.

\section{REFERENCES}

Ainsworth, M., and Eveleigh, J. W. (1952). A Method of Estimating Lung Air-way Resistance in Humans. Ministry of Supply, C.D.E.E. Porton Technical Paper 320

Gaensler, E. A. (1951). Science, 114, 444.

Gandevia, B., and Hugh-Jones, P. (1957). Thorax, 12, 290.

Gielen, E. (1957). Action des poussieres et d'agents pharmacody namiques sur la fonction respiratoire, 5ème partie: Action des Aérosols d'aleudrine chez 311 mineurs encore au travail. Institut d'Hygiène des Mines, Hasselt. Communication No. 145.

Gilson, J. C., and Hugh-Jones, P. (1955). Spec. Rep. Ser. med. Res. Coun. (Lond.), No. 290.

Kennedy, M. C. S. (1953). Thorax, 8, 73.

Lilly, J. C. (1950). Methods in Medical Research, vol. 2, p. 113. J. C. (1950). Methods in M. M. H. Comroe).
Chicago. (ed. J.

Mead, J., and Whittenberger, J. L. (1954). J. appl. Physiol., 6, 408. Mead, J., and Whittenberger, J. L. (1954). J. appl. Physiol., 6, 408. rooms. Third Interim Report of the Joint Advisory Committee of the Cotton Industry. H.M. Stationery Office, London.

Neergaard, K. von, and Wirz, K. (1927). Z. klin. Med., 105, 51. Prausnitz, C. (1936). Spec. Rep. Ser. med. Res. Coun. (Lond.), No. 212 .

Schilling, R. S. F., Hughes, J. P. W., Dingwall-Fordyce, I., and Gilson, J. C. (1955). Brit. J. industr. Med., 12, 217.

Vuilleumier, P. (1944). Z. klin. Med., 143, 698.

Worth, G., Valentin, H., Venrath, H., Gasthaus, L., and Hoffmann H. (1956). Arch. Gewerbepath. Gewerbehyg., 14, 269. 